CASE REPORT

\title{
Demographic Profile, Clinical and Analysis of Osteoarthritis Patients in Surabaya
}

\author{
Ilham Wildan Ahmad ${ }^{1 *}$, Lita Diah Rahmawati ${ }^{2}$, Teddy Heri Wardhana ${ }^{3}$
}

\author{
${ }^{1}$ Medical Student Faculty of Medicine, Universitas Airlangga Surabaya, Indonesia \\ ${ }^{2}$ Department of Internal Disease, , Faculty of Medicine Universitas Airlangga - Dr. Soetomo General Hospital, Surabaya, \\ Indonesia \\ ${ }^{3}$ Department of Orthopaedic and Traumatology, Faculty of Medicine Universitas Airlangga - Dr. Soetomo General \\ Hospital, Surabaya, Indonesia
}

\section{A R T I CLE I N F O}

\section{Article history:}

Received 28 April 2018

Received in revised form 24 May

2018

Accepted 28 April 2018

Available online 30 April 2018

\section{Keywords:}

Knee osteoarthritis,

Age,

Gender,

Kellgren-Lawrnce scoring system,

Knee osteoarthritis severity index.

*) Corresponding author:

ilhamwildan.a@gmail.com

\begin{abstract}
A B S T R A C T
Introduction: Osteoarthritis is a degenerative joint disease which affects joint cartilage. Almost $80 \%$ patients movement are limited and $25 \%$ of them can not even perform daily activities. Due to its chronic and progressive nature, socio-economic impacts in many developed and developing countries are enormous. We aimed to determine the profile of patients with osteoarthritis in Dr. Soetomo General Hospital Surabaya.

Methods: This was an observasional research. Questionnaires data were obtained from September-October 2016. Thirty five subjects with osteoarthritis were analyzed for the study. The variables observed include sex, age, body mass index, type of osteoarthritis, Kellgren-Lawrence scoring system, and knee osteoarthritis severity index.

Results: The result shows that $43 \%$ of the samples were aged $60-69$ years, $83 \%$ of the samples were female, $37 \%$ of the samples had an I BMI obesity, $60 \%$ of samples had bilateral osteoarthritis, and $77 \%$ of samples from primary osteoarthritis. A total of 15 of 53 knee samples had class III, and 15 of 53 knee samples also had class I, and as many as 21 of the 35 samples had a "very severe" clinical gradation. These results may be due to patients who have low grade gradation clinics and have received medical attention at the level I health facility or II.

Conclusion: From the results of this study, it can be concluded that age, sex, BMI, Kellgren-Lawrence assessment system, index severity of patients Lequesne osteoarthritis in Dr. Soetomo General Hospital Surabaya is in conformity with research that has been done in many places and theories that exist.
\end{abstract}

\section{Introduction}

Osteoarthritis is a degenerative joint disease, which affects joint cartilage. It is associated with aging and is likely to affect joints that have been constantly exposed to stress throughout the year (WHO, 2015). According to WHO the prevalence of osteoarthritis worldwide in men is $9.6 \%$ and in women aged over 60 years as many as $18 \%$. While in Indonesia, the prevalence of osteoarthritis at the age of 61 years is 5\%. Meanwhile, the prevalence of knee osteoarthritis is still quite high in
Indonesia, which account $15.5 \%$ in men and $12.7 \%$ in women of the total Indonesian population which amounts to 255 million people (Koentjoro, 2010).

Osteoarthritis is one of the ten most disabling diseases in the developed world. Due to its chronic and progressive nature, the socio-economic impacts in many developed and developing countries are enormous. Diseases that cause severe pain and disability in patients, thus interfering with daily activities. As a result, as many as $80 \%$ have limitations in the move and $25 \%$ of them can not even carry out daily activities (WHO, 2016). 
Based on radiological features, the most commonly used method for defining radiography is Kellgren-Lawrence has been used for more than four decades. The OA assessment system has five levels from 0 to 4 , in Kellgren-Lawrence grading system divided according to the presence of osteophytes of joint space constriction, and the presence of sclerosis of the subcondrial bone (Zhang \& Jordan, 2010). In addition to the radiological picture, the knee osteoarthritis severity index from Lequesne also can be used to assess the severity of the osteoarthritis incidence. Developing a severity index for knee osteoarthritis can also be used to assess the effectiveness of therapeutic interventions(Lequesne et al., 1987).

The high prevalence of osteoarthritis in Indonesia, the variety and severity of the disease based on the Kellgren-Lawrence criterion, and the presence of risk factors that affect the incidence, pain, disability, and severity of the underlying disease are the reason the investigators want to know more in demographic, clinical and index profiles severity of knee osteoarthritis patients in outpatient clinic of Dr. Soetomo General Hospital Surabaya.

\section{Methods}

This is descriptive research with cross sectional approach using primary data. The samples were all patients of knee osteoarthritis found in Outpatients Clinic of Rheumatology, Internal Disease and Outpatients clinic of Orthopedic and Traumatology DR. Soetomo General Hospital Surabaya which obtained by total sampling. Variables used include demographics, primary and secondary osteoarthritis, Kellgren-Lawrence grading system, and Leodesne severity index. Primary data was obtained through direct inquest to the patient, BMI data obtained by direct measurement, data degrees of joint damage obtained from radiological examination, and data of severity and demographic index obtained through direct questioning to patients with questionnaires. The steps of data processing are checking the completeness and clarity of the data, coding on each variable data, entering the data into the computer program, and checking again to ensure that the data has been cleared of errors.

\section{Results}

\section{General Characteristic Respondents}

The results of measurements conducted in Outpatients Clinic of Rheumatology, Internal Disease and Outpatients clinic of Orthopedic and Traumatology DR. Soetomo General Hospital Surabaya, from September 2016-October 2016 researchers obtained 35 patients knee osteoarthritis who became the study sample. The age group of the most studied sample was aged 60-69 years which is 15 samples $(43 \%)$. Then the remainder at age 50-59 years were 10 samples (29\%), at age 40-49 years in 7 samples $(20 \%)$, and at age $70-79$ years in 3 samples $(8 \%)$. Woman was the most knee osteoarthritis patient
(K/L), a radiographic gradation scheme that

who became the samplew which is 29 samples $(83 \%)$ compared to males with only 6 samples (17\%) (Table 1). Table 1 Distribution of Osteoarthritis Patients Age, Gender, BMI Respondents

The spread of BMI in knee osteoarthritis patients

\begin{tabular}{cccc}
\hline Variable & $\begin{array}{c}\text { Number } \\
\text { (People) }\end{array}$ & Percentage(\%) \\
\hline Age & & 7 & 20 \\
& $40-49$ & 10 & 29 \\
$50-59$ & 15 & 43 \\
$60-69$ & 3 & 8 \\
\hline $70-79$ & & \\
Gender & 6 & 17 \\
Male & 29 & 83 \\
\hline Female & & \\
\hline BMI & 1 & 3 \\
& $<18,5$ & 10 & 29 \\
$18,5-22,9$ & 6 & 17 \\
$23-24,9$ & 13 & 37 \\
$25-29,9$ & 5 & 14 \\
\hline
\end{tabular}

who treated in Outpatients Clinic of Rheumatology, Internal Disease and Outpatients clinic of Orthopedic and Traumatology DR. Soetomo General Hospital Surabaya mostly have BMI $25-29,9$ or Obesity I (mild) with amount of 13 sample (37\%), then followed by sample with BMI 18,5-22,9 or Normal Weight of 10 samples $(29 \%)$, then samples with BMI 23-24,9 or Preobesity were 6 samples $(17 \%)$, samples with BMI> 30 or Obesity II (heavy) were 5 samples (14\%), and last sampled with BMI $<18.5$ or less weight only amounted to 1 sample $(3 \%)$. (Table 1 )

\section{Knee Patient Distribution Affected by Osteoarthritis}

Patients with osteoarthritis in both knees occupied the highest number of 21 samples, whereas patients with osteoarthritis in the right knee only were 9 samples, and the lowest were patients with left knee osteoarthritis alone of 5 samples (Table 2)

Table 2 Knee Distribution Affected by Osteoarthritis

\begin{tabular}{cc}
\hline Type of knee & Number (Knee) \\
\hline Right only & 9 \\
Left only & 5 \\
Right and Left & 21 \\
\hline Patients Total & 35 \\
Knee Total & 56 \\
\hline
\end{tabular}

\section{Distribution of Osteoarthritis Type}

Type of osteoarthritis patients who seek treatment were patients with primary osteoarthritis more with 27 samples $(77 \%)$ than patients with secondary osteoarthritis amounted to 8 samples $(23 \%)$. (Table 3 ). 
Table 3 Distribution of Osteoarthritis Type Respondent

\begin{tabular}{lll}
\hline $\begin{array}{l}\text { Osteoarthritis } \\
\text { Type }\end{array}$ & $\begin{array}{l}\text { Patients total } \\
\text { (People) }\end{array}$ & Percentage(\%) \\
\hline Primary & 27 & $77 \%$ \\
Secondary & 8 & $23 \%$ \\
\hline TOTAL & 35 & $100 \%$ \\
\hline
\end{tabular}

\section{Distribution of Kellgren-Lawrence grading system}

Based on the Kellgren-Lawrence grading system distribution, the patients with grade I knee left assessment were 5 samples, and the right knee were 10 samples, then the patients with grade II of the left knee were 6 samples, and the right knee were 8 samples, then the patients with grade III knee left assessment was 8 samples, and right knee were 7 samples, last patient with grade IV grade of left knee were 7 samples, and right knee totaled 5 samples. (Table 4)

Table 4 Distribution of Kellgren-Lawrence grading system

\begin{tabular}{cccc}
\hline Grade & Left & Right & Knee Total \\
\hline I & 5 & 10 & 15 \\
II & 6 & 8 & 14 \\
III & 8 & 7 & 15 \\
IV & 7 & 5 & 12 \\
\hline Total & 26 & 30 & 56 \\
\hline
\end{tabular}

\section{Distribution of Knee Osteoarthritis Severity Index from Lequesne}

Knee Osteoarthritis Severity Index of Lequesne, patients with clinical gradation "very severe" or with value >= 14 have the highest number of 21 samples, followed by knee osteoarthritis patients with clinical gradation "very severe" or with the value of 11-13 amounted to 5 samples, then patients with knee osteoarthritis with a median gradation of "moderate" or with a 1-4 score of 4 samples, then patients with knee osteoarthritis with "severe" clinical gradation or with a score of 8-10 were 3 samples, and the last patient with osteoarthritis knee with "adequate" clinical gradation or 5-7 score of 2 samples (Table 5)

Table 5 Distribution of Knee Osteoarthritis Severity Index from Lequesne

\begin{tabular}{cccc}
\hline Value & Legend & $\begin{array}{c}\text { Number } \\
\text { (people) }\end{array}$ & Percentage (\%) \\
\hline $1-4$ & Mild & 4 & $11 \%$ \\
$5-7$ & Moderate & 2 & $6 \%$ \\
$8-10$ & Severe & 3 & $9 \%$ \\
$11-13$ & Very severe & 5 & $14 \%$ \\
$>=14$ & Extremely severe & 21 & $60 \%$ \\
\hline & TOTAL & 35 & $100 \%$ \\
\hline
\end{tabular}

\section{Discussion}

Of the total 35 samples of the youngest age of patients knee osteoarthritis in this study was 40 years, while the oldest was 71 years. There were no patients with knee osteoarthritis under 40 years old. The average age of patients suffering from knee osteoarthritis in this study was 59.08 years. This is because osteoarthritis is a degenerative disease that is the dominant factor is age, but also there are patients who with age range 40-49 years may be due to the patient has secondary osteoarthritis caused by other diseases.

Age is the most dominant factor of osteoarthritis among other factors. Mechanisms suspected to cause joint damage are not known, but joint damage may occur multifactorially including oxidative damage, cartilage thinning, muscle weakening, and proprioceptive weakness (Palazzo et al., 2016). Increased age causes the tension properties of the cartilage to decrease resulting in an accumulation of glycation that causes mechanical failure (Ashkavand et al., 2013). The body's ability to repair cartilage also decreases with age (Simon, 2012).

In another study found the same results that the distribution of age group of patients with osteoarthritis knee samples is the highest on 60-69 years of age, with a minimum age of 52 years, and a maximum age of 91 years. The average age in the study was 67.40 years (Hasiibi, 2014).

In this study the gender of patients with knee osteoarthritis is mostly women as many as 29 patients (83\%), while male knee osteoarthritis patients only amounted to $6(17 \%)$. This proves that the female sex becomes one of the risk factors for knee osteoarthritis, because in women affected by hormonal. In men the occurrence of osteoarthritis may be due to other things such as heavy work that often use the knee as a support.

A significant decrease in estrogen levels after menopause results in an increased incidence of $\mathrm{OA}$ in women over 50 years. Chondrocytes have functional estrogen receptors, which show that these cells are affected by estrogen (Firestein \& Kelley, 2009).

A study in Surakarta City, Lawean District also showed that more women (12 samples) were having osteoarthritis compared to men for 5 sample(Jatmiko, 2015). Another study in Bangli Regency, Bali. Shows that the proportion of knee osteoarthritis patients on men and women knee osteoarthritis patients is almost comparable ie (47.4\% and 52.6\% respectively) (Hasiibi, 2014).

From the data of this study the prevalence of BMI in knee osteoarthritis patients showed that most samples had BMI 25-29.9 or Obesity I (mild) that accounted to 13 samples (37\%), and the fewest samples with BMI $<18.5$ or less weight only amounted to 1 sample (3\%). These results proved that BMI has a close relationship to become one of the risk factors for osteoarthritis. There is also one sample with underweight 
(3\%), osteoarthritis can indeed occur in people with BMI "underweight" but the percentage is relatively small compared to other BMI groups. This may be due to the possibility that patients with BMI "less weight" find other risks such as advanced age, heavy occupation, or due to other diseases or secondary osteoarthritis.

Research shows that obesity has a positive relationship with osteoarthritis genu (Ashkavand et al., 2013) Obesity also accelerates the progression of osteoarthritis when the damage has started. This is because in people with obesity, joints must withstand heavier loads so that increase damage risk (Simon, 2012). Some researchers have shown an association between BMI and Osteoarthritis, for every 5-digit increase in BMI will increase the risk factor for osteoarthritis 35\% (Palazzo et al., 2016).

Another study at Dr. M. Djamil Padang General Hospital produces the same data that osteoarthritis is more common in overweight people than normal people. In this study, 6 patients have normal BMI, while patients who have overweight BMI as many as 18 samples of patients from the total sample of 24 patients samples. (Mutiwara, 2016).

The results showed that bilateral knee osteoarthritis patients were more numerous with 21 samples (60\%), while patients with unilateral knee osteoarthritis accounted for 14 samples (40\%). This can happen because many of the patients on the sample have an excess BMI, and the entire body weight is supported by 2 knees, resulting in bilateral symmetry. In patients with unilateral osteoarthritis may be due to trauma, or often use only one of the legs to become a cure during the move.

From the radiographic features of the joints, narrowing of joint cracks is often asymmetrical and heavier the knees are often used to support body weight (Soeroso, 2006). Other researchers say in his research the incidence of bilateral osteoarthritis is often associated with excess BMI, and unilateral osteoarthritis is often associated with injury(Davis et al. 1989).

In a study of knee osteoarthritis patients in Dr. M. Djamil Padang General Hospital obtained the same result that the distribution of bilateral knee osteoarthritis patients were 16 samples $(66.7 \%)$, while unilateral knee osteoarthritis patients were 8 samples (33.3\%) (Mutiwara, 2016).

In this study found the incidence of primary osteroarthritis (77\%) higher than secondary osteoarthritis $(23 \%)$. This is because the multifactor that influenced it, and has been proven in the previous discussion that most patients with osteoarthritis in Dr. Soetomo General Hospital Surabaya are elderly, has a BMI above normal, and women. Those data support the results of research showing that the incidence of primary osteoarthritis more. The occurrence of secondary osteoarthritis in this study is often caused by diseases such as trauma, rheumatoid arthritis, spondyloarthritis, and others.

Primary osteoarthritis or idiopathic OA has not been identified and is not associated with systemic disease or local change processes in the joints(Soeroso et al., 2006). However, in primary $\mathrm{OA}$, the degenerative process is still considered the main cause of osteoarthritis disease and is common in patients over the age of 40 years (Lubis et al., 2012).

Another research study at RS. Islam Bandung in 2014 found that the incidence of primary knee osteoarthritis was higher than secondary, and from that study it was also found that primary knee osteoarthritis was higher in women $(82.54 \%)$ than in men $(18.59 \%)$ (Sonjaya et al., 2015).

Based on the Kellgren-Lawrence grading system, knee osteoarthritis patients grade I and grade III were 15 samples, grade II were 14 samples, and grade IV were 12 samples. In this research, the distribution between the degree of severity is relatively even. In the current era of Jaminan Kesehatan Nasional (National Health Insurance) in Indonesia, for type A hospitals such as Dr. Soetomo General Hospital Surabaya should have more cases with a high degree of severity because cases with first degree severity generally can be overcome in first-rate health facilities such as Puskesmas or Klinik Pratama (Community Health Center). The results of the study did not show that kind of results possibly because some patients did not yet have Jaminan Kesehatan Nasional or the therapy given at the first-rate health facility has not been able to reduce the pain suffered by the patient. The number of patients with grade I knee osteoarthritis was very different based on the Lequesne severity index data that showed most patients have very severe clinical gradations, this also proved that the pain suffered by the patient is very subjective and not directly proportional to the reading of radiographic results, or maybe something is missed in radiographic reading.

The most commonly used method for assessing the severity of osteoarthritis is Kellgren-Lawrence $(\mathrm{K} / \mathrm{L})$, a sequel of radiographic gradation that has been used for 4 decades. Overall the OA scoring system is five levels from 0 to 4, in Kellgren-Lawrence grading system theory divided according to the presence of osteophytes of joint space constriction, and the presence of sclerosis of the subcondrial bone (Zhang \& Jordan, 2010).

The results of other studies at RSUP Dr Wahidin Sudirohusodo Makassar showed that based on the distribution of grading frequencies according to Kellgren-Lawrence grading system, the most common cases were third-degree $(61,4 \%)$, followed by fourthdegree $(26,7 \%)$ and second-degree $(11.9 \%)$. The first degree in the study was not found, because the subjects needed medical help when the knee pain was experienced monthly to annual, resulting in an anatomic changes around the knee joint seen in conventional knee joint photographs (Lukum et al., 2011).

Based on research data, the distribution of knee Osteoarthritis Severity Index from Lequesne found that clinical gradation "very severe" was mostly found with value $\geq 14$ score of $60 \%$, shile the least patients with "adequate" clinic gradation of $6 \%$. This is because in the era of national health insurance (JKN) apply the system 
of health facilities (fasilitas kesehatan/faskes) is divided into primary, secondary and tertiary health care. Dr. Soetomo General Hospital included on tertiary health care whereas patients with osteoarthritis were already treated by primary or secondary health care. However, the data showed patients with "moderate" clinical gradations persisted and even higher than patients with clinically "adequate" gradations despite the JKN era, this may occur because some patients have not or do not use JKN, or because of pain is subjective assessment there are some patients who do not often complain about the pain. From the overall result also proves that there is no direct correlation between Lequesne severity index and Kellgren-Lawrence grading system.

Another study at Prof. Dr. R.D. Kandou Manado General Hospital, the incidence of knee osteoarthritis has a clinical gradation of the moderate Lequesne index of $42.11 \%$, and only one person $(2.63 \%)$ with clinical gradation of the Lequesne index is very severe (Yaputri, 2005).

\section{Conclusion}

The average age of the sample in this study was 59.08 years with women as majority. Most samples belong to first degree obesity that is equal to $37 \%$. In this study, more cases were primary osteoarthritis with value $77 \%$ and most cases were bilateral, $60 \%$. Based on the Kellgren-Lawrence grading system, most cases dound were first and third-grade, 15 for each cases. Based on the Severity Index of Lequesne, most cases found were in clinical gradation "very severe" (value $\geq 14$ ) that is equal to $60 \%$.

\section{Conflict of Interest}

The author stated there is no conflict of interest.

\section{References}

1. AAOS, 2014. Arthritis of the Knee. Available at: http://orthoinfo.aaos.org/topic.cfm?topic=a00212 [Accessed January 24, 2017].

2. Ashkavand, Z., Malekinejad, H. \& Vishwanath, B.S., 2013. The pathophysiology of osteoarthritis. Journal of Pharmacy Research, 7(1), pp.132-138.

3. Davis, M.A. et al., 1989. The association of knee injury and obesity with unilateral and bilateral osteoarthritis of the knee. American journal of epidemiology, 130(2), pp.278-88. Available at: http://www.ncbi.nlm.nih.gov/pubmed/2750727 [Accessed January 24, 2017].

4. Firestein, G.S. \& Kelley, W.N., 2009. Kelley's textbook of rheumatology, Saunders/Elsevier.

5. Hasan, M. \& Shuckett, R., 2010. Clinical features and pathogenetic mechanisms of osteo-arthritis of the hip and knee | BC Medical Journal. BCMJ, Vol. 52(BCMJ), pp.393-398. Available at: http://www.bcmj.org/article/clinical-features-andpathogenetic-mechanisms-osteo-arthritis-hip-and-knee [Accessed January 24, 2017].

6. Hasiibi, W.A., 2014. Prevalensi dan Distribusi Osteoartritis Lutut Berdasarkan Karakteristik Sosio-
Demografi dan Faktor Risiko di Wilayah Kerja Puskesmas Susut I, Kecamatan Susut, Kabupaten Bangli Pada Tahun 2014. , (April), pp.1-10.

7. Hinman, R.S. \& Crossley, K.M., 2007. Patellofemoral joint osteoarthritis: An important subgroup of knee osteoarthritis. Rheumatology, 46(7), pp.1057-1062. Available at: http://rheumatology.oxfordjournals.org/content/46/7/1057. full.pdf + html.

8. Jatmiko, S.W., 2015. Hubungan Obesitas dengan Terjadinya Osteoartritis Lutut Pada Lansia Kecamatan Laweyan Surakarta. , 7, pp.15-18. Available at: http://journals.ums.ac.id/index.php/biomedika/article/dow nload/1587/1124.

9. Koentjoro, S.L., 2010. hubungan antara Indeks Masa Tubuh (IMT) dengan Derajat Osteoartritis Lutut Menurut Kellgren dan Lawrence. Journal of bone and mineral metabolism. Available http://eprints.undip.ac.id/23723/1/Sara_Listyani.pdf.

10. Koesoemawati et al., 2000. Kamus Kedokteran Dorland 29th ed., Jakarta: EGC.

11. Lequesne, M.G. et al., 1987. Indexes of Severity for Osteoarthritis of the Hip and Knee: Validation-Value in Comparison with Other Assessment Tests. Scandinavian Journal of Rheumatology, 16(sup65), pp.85-89. Available at:

http://www.tandfonline.com/doi/full/10.3109/0300974870 9102182 [Accessed January 23, 2017].

12. Lubis, V.K. et al., 2012. Implantasi Sel Punca Mesenkimal Autolog pada Cedera Tulang Rawan Sendi Lutut. , 39(6), pp.463-464.

13. Lukum, E.M. et al., 2011. Hubungan Derajat Nyeri Berdasarkan Visual Analogue Scale (VAS) Dengan Derajat Radiologik Berdasarkan Kellgren Lawrence Score Pada Foto Konvensional Lutut Pasien Osteoartritis Sendi Lutut. Available at: http://pasca.unhas.ac.id/jurnal/files/856a11420db1bdc154 0c72e8dd67d9f5.pdf.

14. Maharani, E.P., 2007. Faktor-faktor Risiko Osteoartritis Lutut. Tesis. Available at: http://eprints.undip.ac.id/17308/1/Eka_Pratiwi_Maharani. pdf.

15. Martel-Pelletier, J., 2004. Pathophysiology of osteoarthritis. Osteoarthritis and Cartilage, 12, pp.31-33.

16. Michael, J.W.-P., Schlüter-Brust, K.U. \& Eysel, P., 2010. The epidemiology, etiology, diagnosis, and treatment of osteoarthritis of the knee. Deutsches Arzteblatt international, 107(9), pp.152-62. Available at: http://www.ncbi.nlm.nih.gov/pubmed/20305774 [Accessed January 24, 2017].

17. Moskowitz et al., 2001. Osteoarthritis 3rd edition Diagnosis and Medical / Surgical Management. 3rd ed., Philadelphia: W.B. Saunders Company.

18. Mutiwara, E., 2016. Artikel Penelitian Hubungan Indeks Massa Tubuh dengan Derajat Kerusakan Sendi pada Pasien Osteoartritis Lutut di RSUP Dr . M . Djamil Padang. , 5(2), pp.376-380. Available at: http://jurnal.fk.unand.ac.id/index.php/jka/article/download 1525/430.

19. Palazzo, C. et al., 2016. Risk factors and burden of osteoarthritis. Annals of Physical and Rehabilitation Medicine, 59(3), pp.134-138. Available at: http://www.ncbi.nlm.nih.gov/pubmed/26904959 [Accessed January 24, 2017].

20. Petersson, I.F. et al., 1997. Radiographic osteoarthritis of 
the knee classified by the Ahlbäck and Kellgren \& Lawrence systems for the tibiofemoral joint in people aged 35-54 years with chronic knee pain. Annals of the rheumatic diseases, 56(8), pp.493-6. Available at: http://www.pubmedcentral.nih.gov/articlerender.fcgi?artid $=1752423 \&$ tool $=$ pmcentrez\&rendertype $=$ abstract.

21. Poole, A.R., 1999. An introduction to the pathophysiology of osteoarthritis. Frontiers in Bioscience, 4(6), p.d662-670. Available at: https://www.bioscience.org/1999/v4/d/poole/fulltext.htm.

22. Simon, H.M., 2012. Osteoarthritis. , pp.1-20. Available at: http://umm.edu/health/medical/reports/articles/osteoarthrit is.

23. Soeroso, J. et al., 2006. Buku ajar ilmu penyakit dalam 4th ed., Jakarta: Pusat Penerbitan Ilmu Penyakit Dalam Fakultas Kedokteran Universitas Indonesia.

24. Sonjaya, M.R., Rukanta, D. \& Widayanto, 2015. Karakteristik Pasien Osteoarthritis Primer di Poliklinik Ortopedi Rumah Sakit Al-Islam Bandung Tahun 2014. Olahraga Rutin Dengan Tingkat Depresi, (581), pp.694699.

25. WHO, 2015. WHO | Chronic rheumatic conditions. WHO. Available at: http://www.who.int/chp/topics/rheumatic/en/ [Accessed January 24, 2017].

26. WHO, 2016. WHO | Obesity and overweight. WHO. Available http://www.who.int/mediacentre/factsheets/fs311/en/ [Accessed January 24, 2017].

27. Yaputri, C., 2005. Hubungan Waktu Tempuh GUG Test dengan Indeks Lequesne pada Penderita Osteoartritis Lutut. Available at: http://eprints.undip.ac.id/12579/1/2005PPDS4820.pdf.

28. Zhang, Y. \& Jordan, J., 2010. Epidemiology of Osteoarthritis. Ann Intern Med, 26(154), pp.355-369. Available at: http://www.ncbi.nlm.nih.gov/pmc/articles/PMC2920533/p df/nihms193462.pdf.

29. Hindy P, Hong J, Lam-Tsai Y, Gress F, 2012. A Comprehensive Review of Esophageal Stents. Gastroenterology \& Hepatology. Volume 8, Issue 8 526534

30. Homs MY, Siersema PD, 2011 Endoscopic palliation of malignant dysphagia and esophageal fistulas in Gineberg GG, Gostout CJ, Kochman ML, North ID, eds. Clinical gastrointestinal endoscopy. Philadelphia: Saunders. 350372

31. Kawasaki R, Sano A, Matsumoto S, 2003. Long-term Outcomes and Complications of Metallic Stents for
Malignant Esophageal Stenoses. Kobe J. Med. Sci. Vol. 49, No. 6, pp. 133-142,

32. Kim TJ, Kim HY, Lee KW, Kim MS, 2009. Multimodality Assessment of Esophageal Cancer: Preoperative Staging and Monitoring of Response to Therapy, Radiographics. 29:403-421

33. Kuwano H, Nakajima H, Miyazaki T, Kato H, 2003. Distinctive Clinicopathological Characteristics in Esophageal Squamous Cell Carcinoma. Ann Thorac Cardiovasc Surg. 9: 6-13

34. Levine MS, Rubesin SE, 2005. Diseases of the Esophagus: Diagnosis with Esophagography. Radiology. 237:414-427

35. Lin SH, Chang JY, 2010. Esophageal cancer: diagnosis and management. Chinese Journal of Cancer. Vol. 29 Issue 10 843-854

36. Martin, et all, 2014. Endoscopic management and prevention of migrated esophageal stents. World J Gastrointest Endosc 2014 February 16; 6(2): 49-54

37. Melhado RE, Alderson D, Tucker O, 2010. The Changing Face of Esophageal Cancer. Cancers. 2: 13791404

38. Mougey A, Adler D, 2008 Esophageal Stenting for the Palliation of Malignant Dysphagia. J Support Oncol. 6:267-273

39. Nederlof N, 2011. End-to-End Versus End-to-Side Esophagogastrostomy After Esophageal Cancer Resection. Ann Surg. 254:226-233

40. Rapici A, Raado G, 2008. Expendable stent for maligna dysphagia. Tech Gastrointestinal Endosc. 10: 175-83

41. Salem AAS, et all, 2012. Self-Expandable Metal Stents in Palliation of Inoperable Esophageal \& GastroOesophageal Carcinoma. Cancer and Clinical Oncology. Vol. 1, No. 1;159-166

42. Sekaal J, et all, 2004. Palliative treatment of advanced oesophageal cancer, Folia Gastroenterol Hepatol. 2 (3): $121-132$.

43. Selinger CP, Ellul P, Smith PA, Cole NC, 2008. Oesophageal stent insertion for palliation of dysphagia in a District General Hospital: experience from a case series of 137 patients. Q J Med. 101:545-548

44. Shim CS., 2012. Esophageal Stent for Cervical Esophagus and Esophagogastric Junction. Clin Endosc. 45:235-239

45. Stahl M., 2010. Esophageal cancer: Clinical Practice Guidelines for diagnosis, treatment and follow-up. Annals of Oncology 21 (Supplement 5): v46-v49

46. Veuillez V, 2007. Multimodal treatment of esophageal cancer. Best practice \& Research Clin gastroenterol 21, 947-63. 